\title{
ENTERTAINMENT OBJECTIVE TRUSTED CITIZEN JOURNALISM TRAINING FOR YOUTH GROUPS IN SOUTH JAKARTA, JAKARTA CAPITAL CITY
}

\author{
Rachmi Kurnia Siregar ${ }^{1 *}$, Liza Dwi Ratna Dewi ${ }^{1}$ \\ ${ }^{1}$ Communication Science Faculty, Budi Luhur University \\ *rachmi.kurnia.@budiluhur.ac.id
}

\begin{abstract}
Youth Groups Activities of Pesanggrahan village and Kebayoran Lama village, South Jakarta rarely published the mass media. These youth groups crave their activities can be informed to public as their self-actualization. Likewise, people wanted to know their activity. This community service activity aimed to inflame their spirit to share information of issues and problems in the local level around them. Hopefully this can preventing the youths drowned to negatives activities. This training divided into three steps: First, delivering basic journalism, news and article writing technique, journalism photography, online journalism; Second, field practice of citizen journalism thereby this youth groups members can be citizen journalist beside news consumers; Third, to published their work in mass media and social blog. Output of this social partnership program are: First, to publish these youth groups activities in mass media and social blog; Second, youth of these groups have ability to make journalism work starting from news and features which supported with journalist photography to publish in social blog and mass media. Conclusion: These Youth Groups need sustainable assistance, monitoring and evaluation so that their journalism work to be able to published in social blog and mass media continuously. These partners also need idea development to stimulating their creativities in domain of citizen journalism.
\end{abstract}

Keywords: Information, Citizen Journalism, Media, Training

\section{INTRODUCTION}

Empowerment of teenagers as young generation being one priority in development. If not directed and trained through trainings and skills, teenagers vulnerable succumbed to negative things which harmful not only for themselves, but also family, the community, the nation. Ranging from riot between students / residents, drug abuse, hiv / aids, liquor, pre marriage sex, pregnancy and early marriages and involved various the crime.

Youth is a nation potential asset. This can see from the hight growth of youth in Indonesia. At 2014 around $25 \%$ or 65 million from 255 million Indonesian people. The problems on faced teenagers in indonesia cause teenager disturbed welfare. Center for Strategis and International Studies (CSIS) Indonesia and the international youth foundation in his report in 2014 express welfare index the youth in Indonesia was in a position to the 19 from 30 countries. One of organization that prepare by government to accommodate youth people necessity and aspiration is to Karang Taruna. Just, youth activities in Karang Taruna looks marginal with the minimum mass media publication. Two of them are Karang Taruna Pesanggrahan Village and Karang Taruna Kebayoran Lama, in South Jakarta, Jakarta Capital City.

Pre studied to Pesanggrahan village indicate Pesanggrahan village divided to 8 areas, name 'Rukun Warga / RW'. Every area has 'Karang Taruna' organization. Karang Taruna RW 02 is the most active one. In accordance with the basic principle Karang Taruna, which as a youth organization to guidance and empowerment of the young generations to improve the social welfare. Whereas pre study to South Kebayoran Lama village indicate that youth in this area offer getting drunk, school dropout, so as to be people with social welfare problems, and vulnerable involved a clash among local people. 


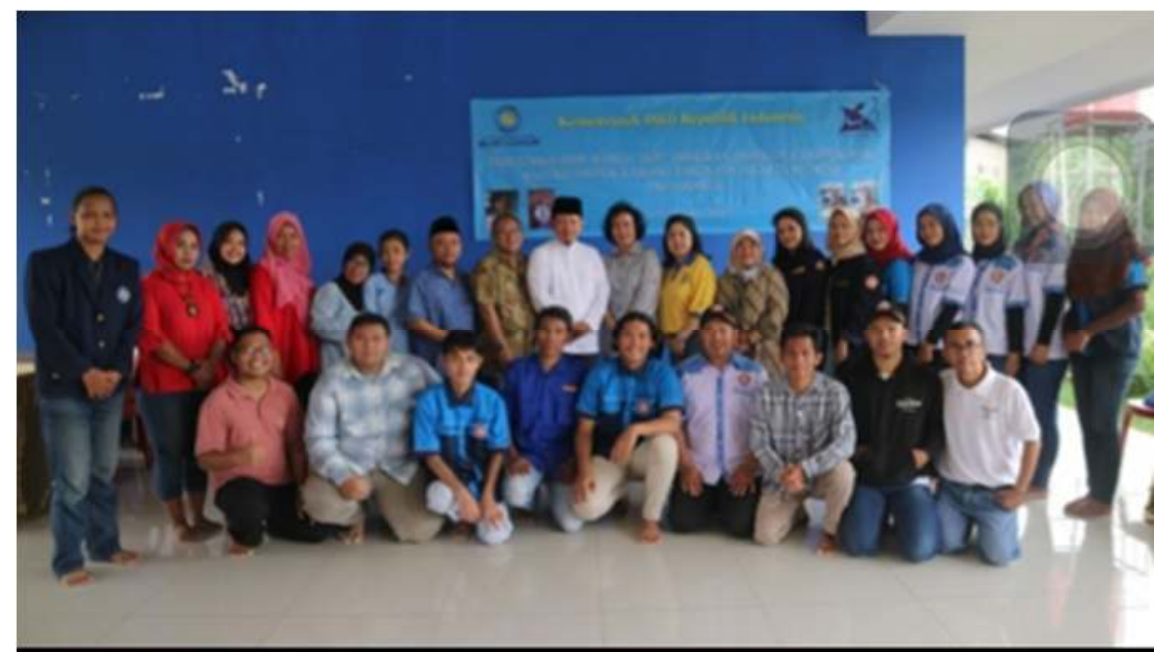

Figure 1. Mentor team with Head of Pesanggrahan Village, and Karang Taruna members

\section{Partners problem}

Both partners for this active with various activities and achievements in socially, youth and community but minimal publicly known because rarely be exposed by mass media. However with publication expected to be better and motivate both partners in devote themselves in public and advance the karang taruna as a receiptacle for the young generation. The ability of both partner for publish of their activities through social blog have a relatively low. Whereas in the digital age range of information can be any time published or known by using the internet facility in a android hand phone. Brooke (2016) describe that "the use of technology in citizen journalism is a new tools of citizens in voicing their own rights and known to the public, as well as to be the representative in society". The absence of knowledge partner residents in journalism skill, cause these group become passive in publish their activities and their existence to a wide audience and society. This is also related to the dissemination of information, experience and local problems in accordance to their passion and capabilities. While through citizen journalism, the target group not only to consumer information but can be active as citizen journalist and a trained individual in critical thinking and writing.

Besides "if a citizen journalist serious and conscientious in their citizen journalism and diligent follow the training journalistic and kept sharpening idea, expertise and skill, writing or reporting, they could be material referral (read and quoted) by journalists of mainstream media". (Kennedy, 2010). "With the rapid development of citizen journalism as the public sphere, in certain countries it become the new social force and media alternative in counter of politics and governance". (Al-Shamsi, 2015). In other words problems partner are:

1.How inflame spirit share information and problems in the local level for the Karang Taruna?

2.How invited Karang Taruna Group to activate citizen journalism?

\section{Target and Outcome}

Journalistic training through citizen journalism is an enormous breakthrough in informing target activities in the mass media, social blog and social media. It must be supported by adequate technology development, especially internet connected. This activity put citizen not only as a recipient of information (consumers), but appeared in the frontline as the party that proactive as information distributor or known as citizen journalist. The information exchange in citizen journalism also influenced the democratization process in Indonesia, improving public insight and knowledge. "Information that distribute must be objective and trusted.And have an entertainment elemen as one of the press functions". (Sumadiria, 2008: 34 ). The solution offered is both partner know journalistic world and has the ability citizen journalism. 


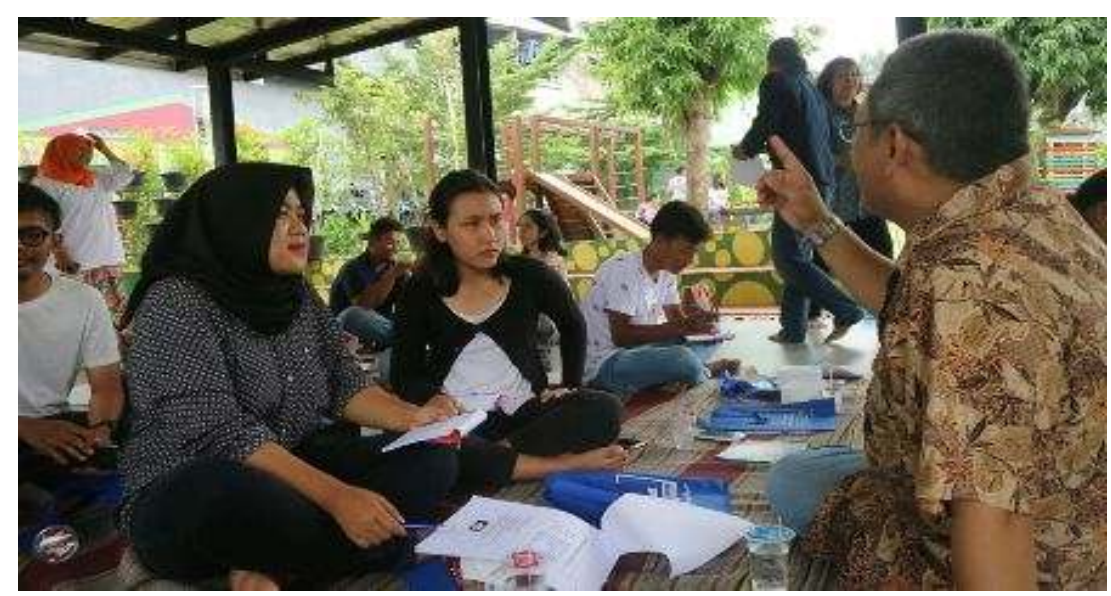

Figure 2. Training and mentoring activitiy Karang Taruna South Kebayoran Lama

The material provided ranging from basic of journalistic, reportase and interview techniques, news writing, articles/features writing techniques, photography journalistic, online journalistic, blog creating to publish Karang Taruna various activities. "In citizen journalism, individual emerged as a producer of information or citizen journalist in addition to consumers. And serve as image builder in virtual public sphere to make self commodification for values they want to be achieved". (Nasrullah, 2013). But citizen journalis as individuals who informs something events or certain things not paid on that job (Chiluwa, Innocent, 2013). These individuals perform a function of professional journalist by providing account, a picture to video at first of an event to immediately known by people.

Outcome that be produced are:

1. Journalistic creation in the form of news supported journalistic photography.

2. Journalistic creation in the form of article /fature journalistic photography.

3. Creating social blog as media to publish creations of both partner members.

4. Publication of partner members journalistic creation in mass media and social blog.

\section{METHOD}

\section{Place and time}

Citizen journalism training conducting at Ruang Publik Terpadu Ramah Anak (RPTRA) ${ }^{l}$ Abdi Praja for Karang Taruna Pesanggrahan and RPTRA Kampung Perigi for Karang Taruna Kebayoran Lama Selatan, every Saturday interchangeably, accompanied by duties and assistance email and group whatsapp (wa). This public service activities was held since april until august 2018, at 08.00-15.00. with two break sessions.

\section{Approach method and design}

...... A major constraint for providing citizen journalism training are the partner still in doubt, fear, lacking in confidence, rarely using internet to read news (although entirely having a smartphone), minimal ideas and lacking of sensitivity toward problems around them. As the solution, team uses bottom-up participatory communication approaach to partner. As well as making struck with the concept of the 'the power of the thumb citizen journalist' by use smartphone. 


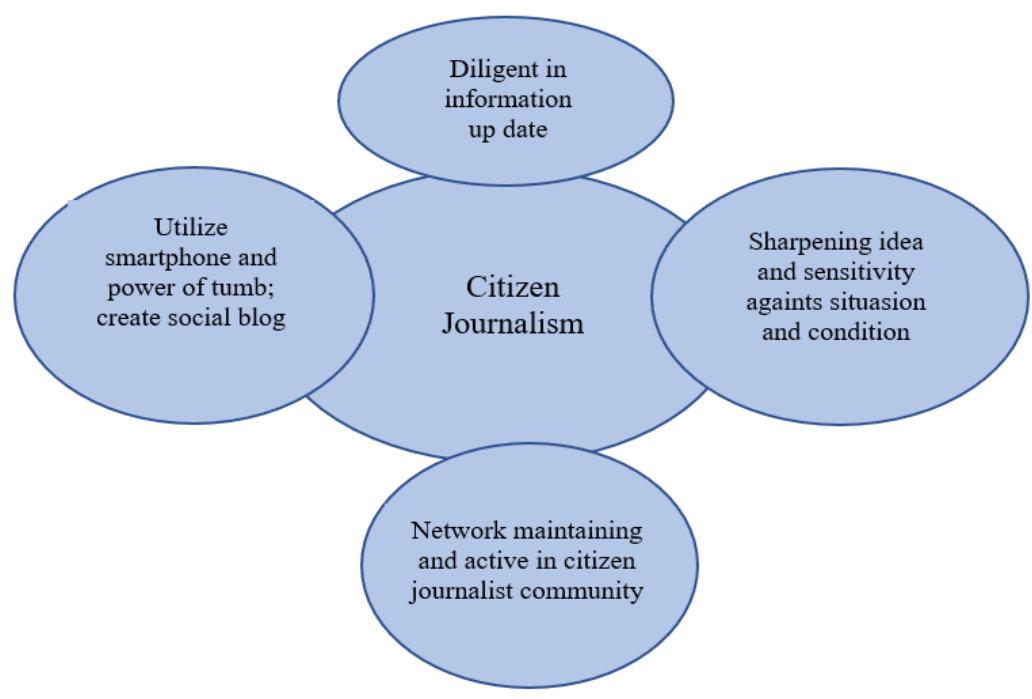

Figure 3. Method Model

\section{Partner participation}

During the conduct of this community service both partner participate from the start to the final stage. At an early stage, partner participating by provided information about the problems faced by partner. On in the implementation stage, routinely partner participate present in any training. At the end, partner make a variety of journalistic works to be published in mass media and social blog.

\section{Outcome produced}

Citizen journalistic training for Karang Taruna Pesanggrahan and Karang Taruna South Kebayoran Lama, South Jakarta, Jakarta Capital City which conducting by lecturer team of Communication Science Faculty, Budi Luhur University produce outcome cover: News supported with journalistic photography; Article/ feature supported with journalistic photography; Social blog; Mass media and social blog publication.

\section{RESULT AND DISCUSSION}

\section{Discussion}

Citizen journalism training for both partner that held since april until august 2018 is outside team expectations. Although partner was very enthusiastic to join these community service activity. The partners general knowledge is lack, so that mastery of ideas is also difficult to find. Curiosity from partners also low. Meanwhile "curiosity supported with accuracy and digital skills very important in supporting the success of journalistic". (Karmas, 2015) Mastery of journalistic even can be one skills in order to support their life achievement the knowledge of a community.

Intensively team deliverd hard training with journalistic material package, covering: the basic of journalism, reporting, technique news writing, technique article/feature writing, journalistic photography, and online journalistic. At the end, partner also train to make and containing social blog. Team created dialogue and discussion room with both partner by Whatsapp Group. This means is become strategic tools in pumping spirit partners to extra work to do the citizen journalism work. The whatsapp group aimed to rallying empowerment partner. Training start with small things and easily to do. The terms are: information being told are not rumors (hoaks); Information must be absolutely the fact that can be relied upon, objective accompanied confirmation of the parties involved (cover booth side). Fox (2013) states "emphasizing the basic essence citizen journalism is has to be liable to the public. This is important for citizen journalist construct and maintain public trust". The mentor team share tips and trick to partner related to citizen journalism. That is practice and easy way to type in 
writing news or article or taking photo by their smartphone. If will be edited and is still inadequate, it continued to work on the notebook or personal computer. Before closing session there are 14 writing creations. But after 2 journalistic works from each partner publish in mass media, the young spirit of these Karang Taruna members starting to revive. Writing work that enter at the editorial desk team reached 24 writing creations and was expected to continue to increase because also be published in social blog each partner.

\section{Result and Outcome Citizen Journalism Training}

*The Dance Hand of PPSU² Guards Pesanggrahan Village

In addition to cleaning the environment and do everything related to infrastructure and facilities as that is under the responsibility of the local village head, PPSU guards Pesanggrahan urban village is also having many capability of being generally rarely seen. Generally their work was nothing more than clean environment from garbage so the environment is clean and beautiful. One is the urban village pesanggrahan PPSU guards ability is very nimble perform a dance of hand.

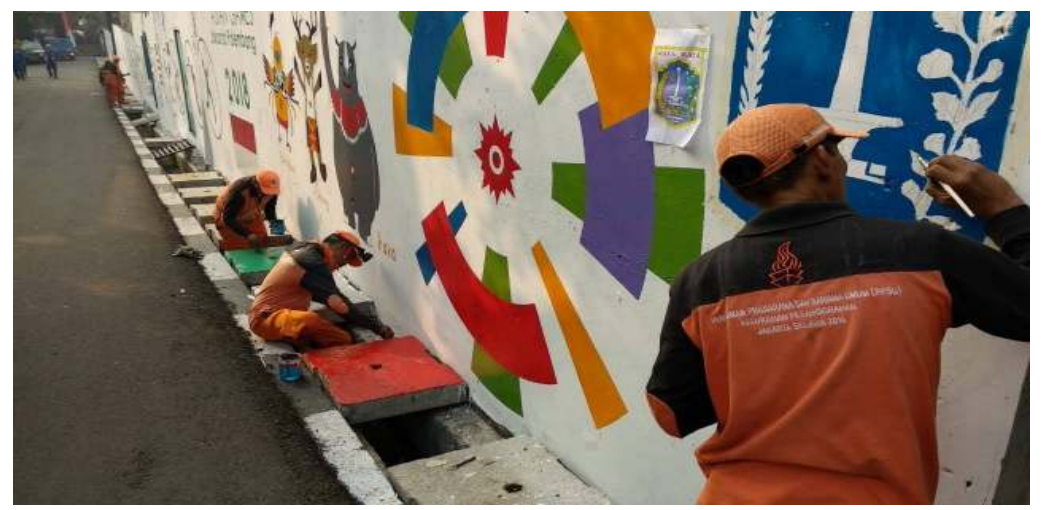

Figure 4. ASIAN GAMES mural creation at wall in front of Pesanggrahan Urban Village office, South Jakarta PPSU, Wednesday (25/07/2018).

(Photo : Fathurrahman Rosidi/Karang Taruna Pesanggrahan Urban Village).

The dance of hand means their high ability in creating a picture. In the wake of asian games 2018 where Indonesia to hostess will be held in two cities: Jakarta and Palembang, make our society very enthusiastic in him in various ways. One way that done by PPSU guards pesanggrahan urban village is to make Asian Games 2018 mural on a wall in front of the office of Pesanggrahan Urban Village. Here creativity PPSU guards Pesanggrahan Urban Village by making mural decoration looked look good and indulgent eyes to the viewer. (Ade R Pamungkas/ Karang Taruna Pesanggrahan Urban Village). Writing work of this PPSU guards has already published in http://pitunews.com/kreasi-mural-ppsupesanggrahan-kenangan-asian-games-2018/

Title and part of the article is as follow: Mural Creation of Pesanggrahan PPSU guards, Asian Games 2018 Memory. Tuesday, September $4^{\text {th }}$,2018. Jakarta, The 2018 Asian Games give alot of memories for the community. Not just the gold medal beyond target, achieving 31 gold, but also opening and closing celebration. Good memories to be left by PPSU guards Pesanggrahan Urban Village who makes creation of 2018 Asian Games Murals. The creation is still can be enjoyed by anyone which pass through on the wall near Pesanggrahan Urban Village Office South Jakarta.

If during this time they only best known to the public proficient in activities cleanliness, but creation the arts of drawing of murals they also should be appreciated. Making the murals is one way support the activities of 2018 Asian Games. PPSU guards of Pesanggrahan Urban Villages make a mural in the july 2018. Painting on the wall (murals) get appreciation from the community. As the host, of course Indonesians enthusiastic in welcoming in various ways. One way done by PPSU guards 
Pesanggrahan Urban Village is to make murals of 2018 Asian Games on a wall in front of the Pesanggrahan Urban Village Office. Besides entertaining, creativity Pesanggrahan Urban Villages PPSU guards in mural making of look good indulge eyes of people who look at. (Writer: Ade R. Pamungkas / Karang Taruna Pesanggrahan Urban Village). Travel report from Tetty of South Kebayoran Lama Karang Taruna and has been published in: https://jurnalcakrawala.com/wisata-pabangbon-rumah-pohon-jadi-pilihan-rekreasi-di-bogor/. The report according to URL Link above is as follow:

Pabangbon Tour, Tree House Become Recreation Alternative in Bogor, September 5, 2018

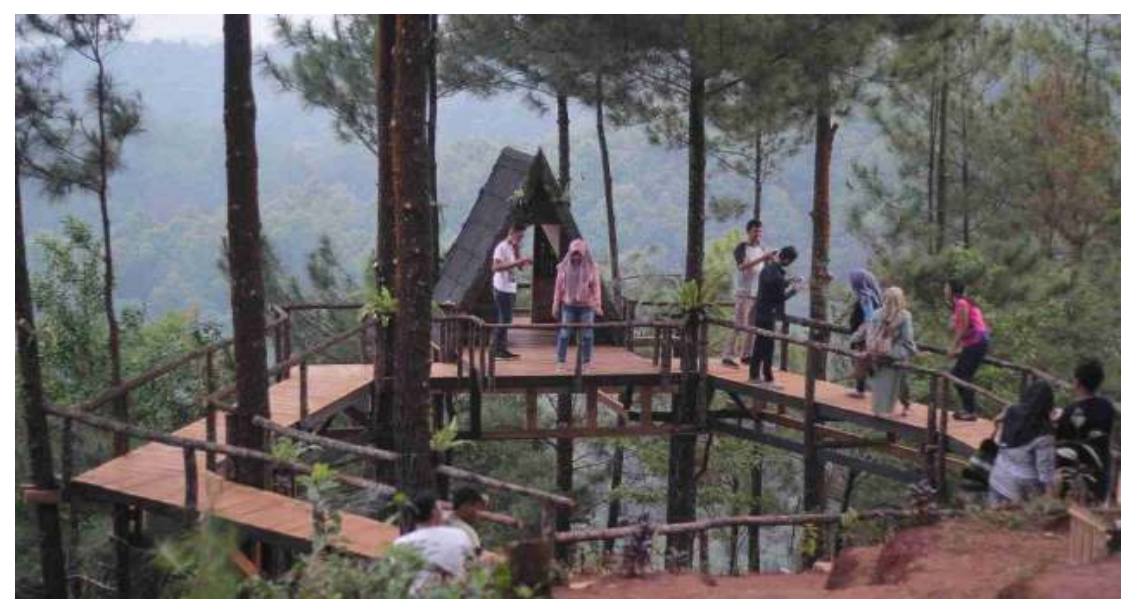

Figure 5. Pabangbon Tour, Tree House Become Recreation Alternative in Bogor, September 5, 2018

KAB.BOGOR-Jurnal Cakrawala.com. there are many tourist destinations which do not expensive but no less of beautifulnes. One of them is Pabangbon located in Leuwiliang, Bogor. Besides is not too far from Jakarta, Pabangbon provides beautiful scenery, and tree house tourism which is not less interesting. Writer and friends visited a natural tourism in Leuwiliang, Bogor West Java, the Pabangbon Tree House, in March 2018. The location is 5 kilometers from Bogor City Center. Need 1,5 hour travel time drive last Sunday (2/9). Nice location to take picture. More interesting one is tree house with beautiful green view. Pabangbon is tourist destination which provide beautiful sceen like the story of fairyland. The panoramic view is nice and exciting to take picture together. If visit Pabangbon we have to make a lot documentation of nice and fun moment together with friend and family We can enjoy the beautiful view performed in the height of 720 meters above sea level in this area. Visitors can enjoy the Pabangbon Panoramic using several photo spot to see beautiful background scenery be attraction for with enshrine moment.

To take photo at this beautiful spot, only charge 5 thousand rupiah. This charge is cheap enough as we can make foto and selfie with beautiful and green panoramic background. The ticket alaso reacheable as only 10 thousand rupiah per person. Writer had a little chat with one of the visitor named Eka from Jakarta. She chose holiday at Pabangbon because of its place cool and beautiful and take a picture. "It is nice weather place, and the entry tickets is so cheap. The landscape is magnificent, after all the location was close from Jakarta. "So, I do not take a lot of time to reach this location", she explain cheerfurly. In addition to traveled in a tree house, we can also tatters in the camp still fused with nature The management of this tourism area also provides tents camps including a gas stove as well as facilities for other portable, also available. Is just in tourism location Pabangbong there are no hotels or villa, or star hotels. But don't worry. We can spend the night in the people houses after having obtained approval from tourism from the management. So it is not just charm natural we can enjoy but also fused by a mood of the natural. If going to enjoy a waterfall, in the region there are also Curug Cilame Pabangbon. You can imagine the beauty and atmosphere traveled in Pabangbon. So, let's enjoy the Pabangbon natural beauty panoramic tourism, in cheap!. (Red) 


\section{CONCLUSION}

Journalistic training through citizen journalism is a breakthrough in information gathering and spreading for the target in the mass media, social blog and social media. This activity put partner position not only as the consumer of information, but appeared in the frontline as the active party as information disseminators or known as citizen journalist. To proceed the training smoothly and successful, the team adopting participative communication with bottom-up pattern. This strategy put a partner as producers and consumers by using technology facilities on their smartphone.

But partner need continue assistance, monitoring and evaluation for their journalictic creation to keep it worthy to be published in the mass media and social blog. Continue assistance also need for reportase idea developing and pumping their creativity as citizen journalist. In order to keep partners interest and do not stopped their spirit in citizen journalism, Karang Taruna Pesanggrahan and Karang Taruna South Kebayoran Lama remains to be developed and monitored by each Urban Village Leader. Means the spirit to share the information related with their local problem should be keep sustain. Because we should be considered by publicizing, at least in the social partners blog, could be one of driving for better area. At the same time, it could increasing partner self confidence, and IT literate by applying citizen journalism in everyday life.

\section{REFERENCES}

Al-Shamsi, Yousof Khaflan. (2015). Freedom of Expression In The Omani Social Media: Comparative Analysis Between Private and Government Owned Media On Facebook. International Journal of Arts \& Sciences, vol. 8(3), 483-495.

https://search.proquest.com/docview/1755489935/D017C9CB763B4580PQ/2?accountid=38628

Brooke, Heather. (2016). Inside The Digital Revolution. Journal of International Affairs, vol. 70(1), 29-53.

https://search.proquest.com/docview/1855797544/fulltextPDF/53A46D7FC22E449CPQ/33?acco untid $=38628$

Chiluwa, Innocent et all. (2013). Twittering the Boko Haram Uprising in Nigeria: Investigating Pragmatic Acts in the Social Media. Africa Today, vol.59(3), 82-102.

https://search.proquest.com/docview/1353651874/53A46D7FC22E449CPQ/43?accountid=38628

Desta, Tedla et all. (2014). Exploring the role of citizen journalism in slum improvement: the case of 'Voice of Kibera'. AI \& Society, vol.29(2), 215-220.

https://search.proquest.com/docview/1512822371/abstract/8B2D39335DD54987PQ/1?accountid $=38628 \#$ center.

Fox, Carl. (2013). Public Reason, Objectivity, and Journalism in Liberal Democratic Societies. Res Publica, vol.19(3), 257-273.

https://search.proquest.com/docview/1434119101/fulltextPDF/5B7465D385D04DE4PQ/2?accou ntid $=38628$

Karmas, Cristina. (2015). No News Is Bad News: Active Learning Saves News Writting. International Journal of Arts \& Sciences, vol.8(6), 69-84.

https://search.proquest.com/docview/1764688510/864E6306CBF2420EPQ/4?accountid=38628\# center

Kennedy, Donald. (2010). The future of science news. Biological Science Database, vol.139(2), 5-65. https://search.proquest.com/docview/210575586/fulltext/5B7465D385D04DE4PQ/13?accountid $=38628$ 
Luthfie, M. (2015). Citizen Journalism Sebagai Aktivitas Baru Warga Di Kabupaten Brebes. Jurnal Komunikatio ISSN 2442-3882, vol I(1) April 2015.

Nugraha, Pepih. (2012). Citizen Journalism. PT Kompas Media Nusantara. Jakarta.

Nasrullah, Rusli. (2012). Kontestasi Pemanfaatan Media Jurnalisme Warga Antara Industri dan Khalayak. Disertasi. Kajian Budaya dan Media, Universitas Gajah Mada.

Panggalih, Sae \& Fatimah, Nurul. (2015). Upaya Pemberantasan Buta Aksara Di Kalangan Perempuan Lansia Dengan Metode Jurnalisme Warga. Jurnal Solidarity ISSN 2252-7133. Fakultas Ilmu Sosial Universitas Negeri Semarang.

http://www.kemsos.go.id/modules.php?name=News\&file=article\&sid=355.

https://www.bkkbn.go.id/detailpost/bkkbntahun-2035-remaja-perempuan-

http://bareskrim.com/2015/05/21/pertumbuhan-remaja-indonesia-25-persen-dari-jumlah-penduduk/

http://www.ejournal.undip.ac.id/index.php/forum/article/view/271

http://www.pewarta-indonesia.com/

http://poskotanews.com/2018/04/15/abdimas-dosen-ubl-gelar-pelatihan-jurnalisme-warga/

http://rri.co.id/post/berita/515019/sorotan_kampus/universitas_budi_luhur_adakan_pelatihan_jurnalis me_warga.html

https://www.suaramerdeka.com/news/baca/31242/tim-dosen-ubl-gelar-jurnalisme-warga

https://suarajatim.co.id/news/abdimas-dosen-ubl-gelar-pelatihan-jurnalisme-warga/

http://poskotanews.com/2018/08/26/dosen-ubl-gelorakan-jurnalisme-warga-bagi-remaja-karangtaruna/

https://presidentpost.id/2018/08/27/dosen-fikom-universitas-budi-luhur-gelorakan-jurnalisme-wargabagi-remaja-karang-taruna/

http://pitunews.com/kreasi-mural-ppsu-pesanggrahan-kenangan-asian-games-2018/

https://jurnalcakrawala.com/wisata-pabangbon-rumah-pohon-jadi-pilihan-rekreasi-di-bogor/. 